CASE REPORT

\title{
Molecular and clinical analysis of a neonatal severe hyperparathyroidism case caused by a stop mutation in the calcium-sensing receptor extracellular domain representing in effect a human 'knockout'
}

\author{
D T Ward, M Z Mughal ${ }^{1}$, M Ranieri $^{2}$, M M Dvorak-Ewell $^{3}$, G Valenti $^{2}$ and D Riccardi $^{4}$ \\ Faculty of Life Sciences, The University of Manchester, Michael Smith Building, Oxford Road, Manchester M13 9PT, UK, ${ }^{1}$ Royal Manchester Children's \\ Hospital, Manchester, UK, ${ }^{2}$ Department of Biosciences, Biotechnologies and Pharmacological Sciences, University of Bari, Bari, Italy, ${ }^{3}$ Ultragenyx \\ Pharmaceutical, Inc., Novato, California, USA and ${ }^{4}$ School of Biosciences, Cardiff University, Cardiff, UK \\ (Correspondence should be addressed to D Ward; Email: d.ward@manchester.ac.uk)
}

\begin{abstract}
Objective: Loss-of-function calcium-sensing receptor (CAR) mutations cause elevated parathyroid hormone (PTH) secretion and hypercalcaemia. Although full Car deletion is possible in mice, most human CAR mutations result from a single amino acid substitution that maintains partial function. However, here, we report a case of neonatal severe hyperparathyroidism (NSHPT) in which the truncated $C a R$ lacks any transmembrane domain $\left(\mathrm{CaR}^{\mathrm{R} 392 \mathrm{X}}\right)$, in effect a full $C A R$ 'knockout'.

Case report: The infant (daughter of distant cousins) presented with hypercalcaemia (5.5-6 mmol/l corrected calcium (2.15-2.65)) and elevated PTH concentrations (650-950 pmol/l (12-81)) together with skeletal demineralisation. NSHPT was confirmed by CAR gene sequencing (homozygous c.1174Cto-T mutation) requiring total parathyroidectomy during which only two glands were located and removed, resulting in normalisation of her serum PTH/calcium levels.

Design and methods: The R392X stop codon was inserted into human CAR and the resulting mutant $\left(\mathrm{CaR}^{\mathrm{R} 392 \mathrm{X}}\right)$ expressed transiently in HEK-293 cells.

Results: $\mathrm{CaR}^{\mathrm{R} 392 \mathrm{X}}$ expressed as a $54 \mathrm{kDa}$ dimeric glycoprotein that was undetectable in conditioned medium or in the patient's urine. The membrane localisation observed for wild-type CaR in parathyroid gland and transfected HEK-293 cells was absent from the proband's parathyroid gland and from $\mathrm{CaR}^{\mathrm{R} 392 \mathrm{X}}$-transfected cells. Expression of the mutant was localised to endoplasmic reticulum consistent with its lack of functional activity.

Conclusions: Intriguingly, the patient remained normocalcaemic throughout childhood $(2.5 \mathrm{mM}$ corrected calcium, $11 \mathrm{pg} / \mathrm{ml}$ PTH (10-71), age 8 years) but exhibited mild asymptomatic hypocalcaemia at age 10 years, now treated with 1-hydroxycholecalciferol and $\mathrm{Ca}^{2+}$ supplementation. Despite representing a virtual CAR knockout, the patient displays no obvious pathologies beyond her calcium homeostatic dysfunction.
\end{abstract}

European Journal of Endocrinology $169 \mathrm{~K} 1-\mathrm{K} 7$

\section{Introduction}

The key determinant of whole-body free ionised calcium homeostasis is the secretion of parathyroid hormone (PTH) under the control of the calcium-sensing receptor (CaR). Loss-of-function point mutations in the CAR gene result in mild-to-moderate increases in PTH secretion known as familial hypercalcaemia hypocalciuria (FHH), with the homozygous inheritance causing life-threatening neonatal severe hyperparathyroidism (NSHPT) $(1,2,3)$. Occasionally, de novo, heterozygous CAR mutations have also been reported to yield NSHPT (4). However, the severity of the resulting condition depends on the identity and precise location of the mutation and the extent of its impairment of CaR activity (5). Whereas the entire CaR protein has been successfully knocked out in mice $(6,7)$, most cases of NSHPT result from a single amino acid substitution resulting in a mutant $\mathrm{CaR}$ that may retain partial receptor function. However, there have now been several reports of CAR gene mutations that cause premature termination in the amino terminal extracellular domain (ECD) $(8,9,10$, $11,12,13,14)$. By lacking any transmembrane or intracellular domains, these proteins would represent in effect full CAR knockouts. While most of these cases involve heterozygous expression resulting in $\mathrm{FHH}$ $(10,11,12,14)$, three such cases involve homozygous inheritance resulting in $\operatorname{NSHPT}(8,9,13)$; however, 
molecular evaluation of these NSHPT-causing mutants is lacking. Here, we report a case of NSHPT caused by a termination sequence in the $\mathrm{ECD}$ of $\mathrm{CaR}\left(\mathrm{CaR}^{\mathrm{R} 392 \mathrm{X}}\right)$ and provide details of the diagnosis, full biomolecular analysis of the resulting fragment and then 11 years of clinical follow-up of the case.

\section{Case report}

The female infant was born at 36 weeks of gestation weighing $2.7 \mathrm{~kg}$. In the neonatal period, she developed jaundice, which was treated by phototherapy. On day 6 of life, she was admitted to hospital with a history of poor feeding and worsening jaundice and was started on intravenous antibiotics after a full septic screen. However, her corrected serum calcium concentration was found to be $5.5 \mathrm{mM}$ and when checked again was found to be $6.03 \mathrm{mM}$ (reference range $2.15-2.65 \mathrm{mM}$ ). The infant's symptomatic hypercalcaemia was managed by intravenous rehydration, oral administration of Furosemide and subsequent feeding of Locasol (low calcium and free of vitamin D) formula milk. These measures were very successful in controlling her hypercalcaemia. Her PTH concentration (checked on four separate intervals) varied from 650 to $950 \mathrm{pM}$ (12-81 pM reference range) and she was mildly deficient in $25(\mathrm{OH})$ vitamin $\mathrm{D}(9.5 \mathrm{ng} / \mathrm{ml} \quad(>20$ considered sufficient)). She also exhibited raised alkaline phosphatase activity (1105 IU/l (70-330 for infants) at the first month rising to $1330 \mathrm{IU} / \mathrm{l}$ in the second month) with radiological evidence of skeletal demineralisation (see Supplementary Figure 1, see section on supplementary data given at the end of this article). The infant's parents are distant cousins but their serum calcium concentrations were within the normal range at the time of the initial investigations (maternal values: 2.59 and $2.65 \mathrm{mM}$ corrected calcium (2.15-2.65), $39 \mathrm{pg} / \mathrm{ml}$ PTH (10-60), $0.85 \mathrm{mM}$ magnesium (0.6-1) and $12.7 \mathrm{ng} / \mathrm{ml} 25(\mathrm{OH}) \mathrm{D}_{3}(n>20)$; paternal values: 2.47 and $2.57 \mathrm{mM}$ corrected calcium, 62 and $42 \mathrm{pg} / \mathrm{ml}$ PTH and $0.92 \mathrm{mM}$ magnesium). There is no other relevant family history. Sequencing of the infant's CAR gene (Oxford DNA sequencing facility) revealed a homozygous c.1174 C-to- $\mathrm{T}$ mutation predicted to cause an early termination in the receptor's ECD, i.e. a loss-of-function mutation confirming the clinical diagnosis of NSHPT. The parents were confirmed to be heterozygous for the mutation by gene sequencing (Fig. 1 and Supplementary Figure 2).

Total parathyroidectomy was performed in her second month of life, although only two glands were located and removed. Nevertheless, this intervention normalised her serum PTH and calcium levels (Fig. 1) and reduced her alkaline phosphatase levels (from 1330 to $707 \mathrm{IU} / \mathrm{l}$ at 6 months post-surgery and 542 at 10 months post-surgery). At 8 years, the patient's biochemical parameters remained normal: $2.5 \mathrm{mM}$

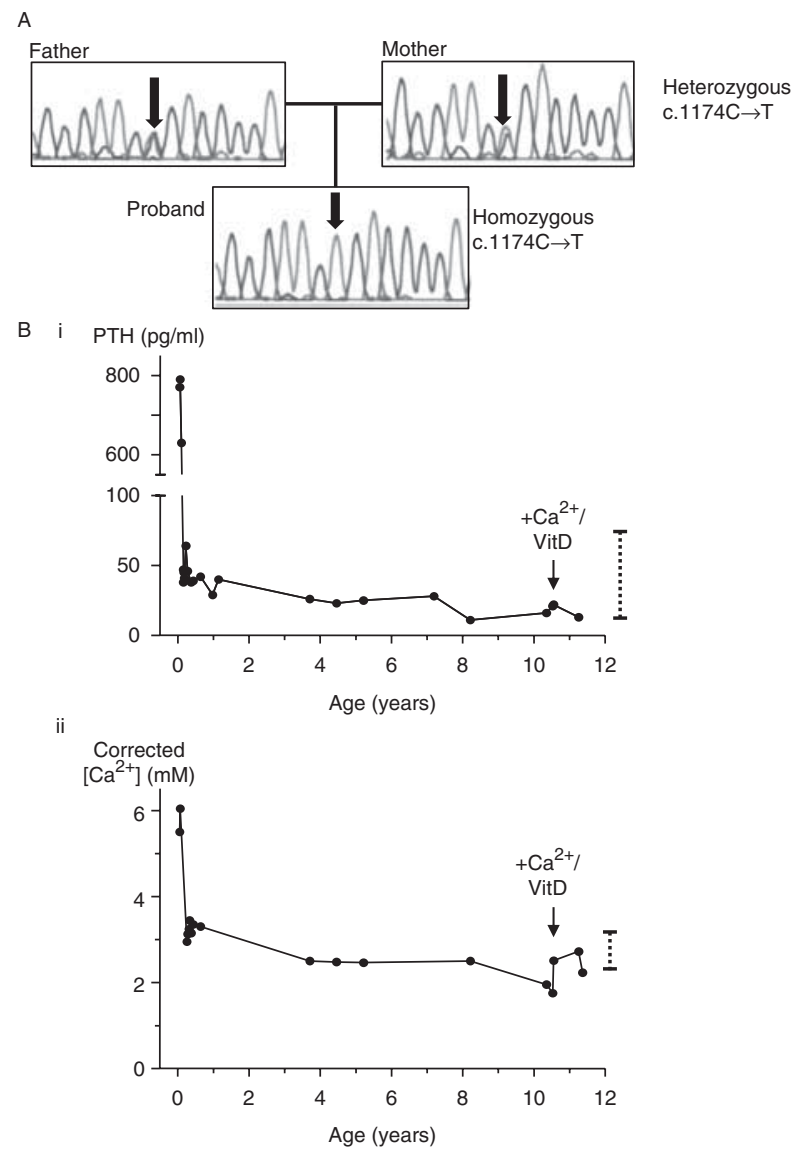

Figure 1 (A) Sequence analysis chromatograms of exon 7 confirming heterozygous expression in the parents and homozygous expression in the proband of the CAR mutation, c1174C $>$ T. Colour versions are available in Supplementary Figure 2, see section on supplementary data given at the end of this article. (B) Corrected blood PTH (i) and calcium (ii) levels from day 6 of life to the present. A downward arrow indicates the beginning of calcium and $1 \alpha$-hydroxycholecalciferol treatment. Reference ranges are indicated by dotted lines on the right-hand side.

calcium, $1.66 \mathrm{mM}$ phosphate, $131 \mathrm{IU} / \mathrm{l}$ alkaline phosphatase, $11 \mathrm{pg} / \mathrm{ml}$ PTH (10-71) and 0.22 urine Ca:Cr ratio $(n<0.52)$ with a normal cranial CT scan and bone mineral density. Despite her residual PTH secretion, no additional glands were located by sestamibi scan at 6 months. However, at age 10 years, the patient exhibited asymptomatic hypocalcaemia $(1.95 \mathrm{mM})$ with $21 \mathrm{pg} / \mathrm{ml}$ serum PTH (10-60) which normalised with daily oral treatment with $0.5 \mu \mathrm{g}$ 1-hydroxycholecalciferol and Calcichew D3 Forte (Fig. 1). Otherwise, the 11 year old is now an apparently healthy child exhibiting above average intelligence (normal head CT scan at age 4 years) having grown normally (between 9th and 25th centile; normal spine and forearm bone density values at age 5 years). The proband's parents provided informed, written consent and the research complied with the Declaration of Helsinki. 


\section{Materials and methods}

\section{Solutions and materials}

All chemicals were purchased from Sigma-Aldrich. Fura-2 AM was obtained from Molecular Probes (Eugene, OR, USA) and NPS-R568 and its less active enantiomer NPS-S568 were a gift from Amgen (Amgen Dompé S.p.a., Milano, Italy).

\section{Site-directed mutagenesis and transient transfection}

The R392X stop codon and an Xbal site were introduced into the full-length human parathyroid CAR cDNA ((15); a gift from Dr Ed Nemeth and NPS Pharmaceuticals, Inc., Salt Lake City, UT, USA) by degenerate PCR (ACAGCCTTCTGACCTCTCTAGACA, degenerate changes in bold). The R392X amplicon was ligated into the pGEM-T cloning vector and then into the pcDNA3.1-hygro using HindIII and Xba1 and finally sequenced to confirm identity.

\section{Cell culture}

HEK-293 cells were grown in DMEM (Invitrogen Ltd.) supplemented with $10 \%$ heat-inactivated fetal bovine serum (FBS; Hyclone, Cramlington, UK). Cells were then transiently transfected with either wildtype (wt) CaR, CaR ${ }^{\mathrm{R} 392 \mathrm{X}}$ or $\mathrm{CaR}^{\mathrm{R} 392 \mathrm{X}-\mathrm{GFP}}$ using Fugene 6 reagent (Roche). After $24 \mathrm{~h}$, the cells were seeded into T75 flasks and incubated for a further $24 \mathrm{~h}$ in $1 \%$ FBS-containing medium.

\section{Immunoblotting}

Conditioned culture medium was collected and the cells were lysed on ice in RIPA buffer supplemented with protease inhibitors and N-ethylmaleimide (NEM; $1 \mathrm{mM}$ ) as described previously $(16,17)$. The conditioned medium (supplemented with $1 \mathrm{mM} N$-ethylmaleimide) and cell lysates were then solubilised in $5 \times$ Laemmli Buffer in the presence or absence of $\beta$-mercaptoethanol and processed for immunoblotting as described previously $(16,17)$. To improve resolution of the wt and mutant receptors, the SDS-PAGE separating gel incorporated a $10 \%(\mathrm{w} / \mathrm{v})$ acrylamide gel (for proteins $<100 \mathrm{kDa})$ beneath a $5 \%(\mathrm{w} / \mathrm{v})$ acrylamide gel (for proteins $>100 \mathrm{kDa}$ ). CaR immunoreactivity was detected using an anti-CaR mouse $\mathrm{MAB}$ and raised to amino acids 214-235 (ADD) of the ECD of the human parathyroid CaR (Affinity Bioreagents, Golden, CO, USA).

\section{Immunofluorescence}

HEK-293 cells were seeded on $10 \mathrm{~mm}$ glass coverslips, grown, transected as described above and fixed for $30 \mathrm{~min}$ with $4 \%$ paraformaldehyde in PBS. Following fixation, cells were permeabilised with $0.1 \%$
TritonX-100 in PBS for 5 min, blocked with 1\% BSA in PBS for $30 \mathrm{~min}$ and incubated for $2 \mathrm{~h}$ with a 1:250 dilution of an anti-calnexin antibody (Santa Cruz Biotechnology), as a marker of endoplasmic reticulum or with 1:200 dilution of anti-TGN46 antibody (Abcam, Cambridge, UK) to stain the Golgi apparatus. After washing three times with PBS-BSA, samples were incubated with 1:1000 diluted goat anti-rabbit antibodies coupled to Alexa-555 in PBS-BSA for $1 \mathrm{~h}$. Next, cells were rinsed three times with PBS and mounted on glass slides with Mowiol mounting solution. Green fluorescence protein (GFP)-tagged CaR was visualised using a Leica TCS SP2 confocal microscope (Leica Microsystems, Heerbrugg, Switzerland) with a $488 \mathrm{~nm}$ filter.

\section{Intracellular calcium imaging}

For intracellular $\mathrm{Ca}^{2+}$ measurements, cells were grown on $40 \mathrm{~mm}$ glass coverslips. HEK-293 cells were loaded with $4 \mu \mathrm{M}$ Fura- 2 acetoxymethylester (AM) for $20 \mathrm{~min}$ at $37^{\circ} \mathrm{C}$ in DMEM. Ringer's solution was used to perfuse cells during the experiment and contained (mM) 140 $\mathrm{NaCl}, 5 \mathrm{KCl}, 1 \mathrm{MgCl}_{2}$, 5 glucose, $1 \mathrm{CaCl}_{2}$ and $10 \mathrm{HEPES}$ ( $\mathrm{pH}$ 7.4). In fluorescence measurements, the coverslips with dye-loaded cells were mounted in a perfusion chamber (FCS2 Closed Chamber System, BIOPTECHS, Butler, PA, USA) and measurements were performed using a Nikon Eclipse TE2000-S inverted microscope (Nikon Ltd, Kingston upon Thames, UK) equipped for single-cell fluorescence measurements and imaging analysis. The sample was illuminated through a $40 \times$ oil immersion objective $(\mathrm{NA}=1.30)$. The fura-2 loaded sample was excited at 340 and $380 \mathrm{~nm}$. Emitted fluorescence was passed through a dichroic mirror, filtered at $510 \mathrm{~nm}$ (Omega Optical, Brattleboro, VT, USA) and captured by a cooled CCD camera (CoolSNAP HQ, Photometrics, Tucson, AZ, USA). Fluorescence measurements were carried out using Metafluor software (Molecular Devices, MDS Analytical Technologies, Toronto, Canada).

\section{Statistical analysis}

Data are reported as mean values \pm s.E.M. with $n$ equal to the number of cells. Responses were analysed as changes in fluorescence intensity and compared with changes induced by a $100 \mu \mathrm{M}$ ATP control stimulus, considered as $100 \%$ in the same cell. The significance of the observations was evaluated by Student's $t$-test for paired data with $P<0.05$ considered to be statistically different.

\section{Results}

Transient transfection of HEK-293 cells with wt human CaR revealed immunoreactivity of an appropriate molecular mass in transfected cells, which was not 
detected in non-transfected cells (Fig. 2A). Western analysis shows that under non-reducing conditions, the CaR migrated as a disulphide-linked dimer, as shown previously (16). Transient transfection of the cells with the R392X mutant revealed significant CaR immunoreactivity $(\sim 54 \mathrm{kDa})$, which was not seen in the non-transfected cells or in the cells transfected with full-length CaR. Under non-reducing conditions, a proportion of this protein migrated as a disulphidelinked dimer (108 kDa; Fig. 2A). As the apparent electrophoretic mobility of the $\mathrm{CaR}^{\mathrm{R} 392 \mathrm{X}}$ mutant $(\sim 54 \mathrm{kDa})$ was less than that expected given its estimated molecular mass $(43.7 \mathrm{kDa}$ including the signal peptide or $41.5 \mathrm{kDa}$ without it), the protein was then treated with PNGaseF prior to immunoblotting, revealing it to be glycosylated (Fig. 2B).

Despite lacking a transmembrane region, no $\mathrm{CaR}^{\mathrm{R} 392 \mathrm{X}}$ was detected in the conditioned medium of transfected HEK-293 cells (Fig. 2C), even when the immunoblot was overexposed. Similarly, no truncated

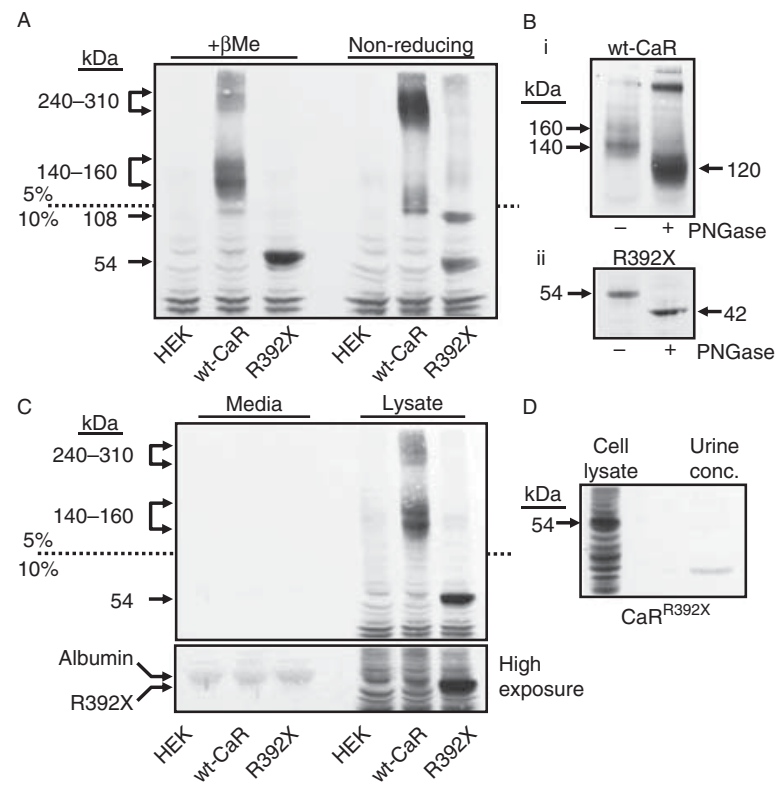

Figure 2 Protein expression of wild-type (wt) CAR and $\mathrm{CaR}^{\mathrm{R} 392 \mathrm{X}}$ proteins in HEK-293 cells. (A) Anti-CaR antibody detects 140, 160 and $240-310 \mathrm{kDa}$ wt-CaR protein bands under reducing conditions and a $54 \mathrm{kDa}$ CaR-reactive band for $\mathrm{CaR}^{\mathrm{R} 392 \mathrm{X}}$ (R392X) but no specific bands in non-transfected, wt cells (HEK). (B) Preincubation with PNGaseF deglycosylated wt CaR to its predicted $120 \mathrm{kDa}$ size and $\mathrm{CaR}^{\mathrm{R} 392 \mathrm{X}}$ to its predicted $42 \mathrm{kDa}$ size. (C) HEK-293 cells transfected as in panel A were cultured for $48 \mathrm{~h}$ prior to collection of conditioned media (Media) cell lysates (Lysate). No CaR immunoreactivity was detected in the conditioned medium. Even when overexposed, the immunoblot revealed no $54 \mathrm{kDa}$ CaR-like signal. A slightly larger protein observed in all three lanes is most likely non-specific detection of serum albumin. (D) Urine collected from the patient was concentrated by centrifugation using Centricon (Millipore, Carrigtwohill, Cork, Ireland) tubes and the proteins solubilised in Laemmli buffer; however, no 54 kDa CaR-like signal was detected in the urinary concentrate either. Lysate from $\mathrm{CaR}^{\mathrm{R} 392 \mathrm{X}}$-transfected HEK-293 cells is included for comparison (R392X).
A

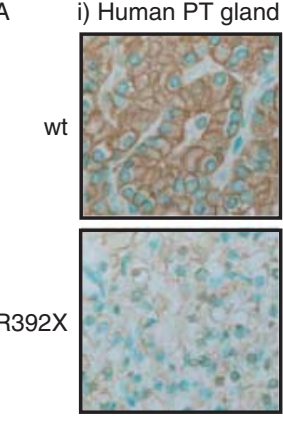

$1^{\circ} \mathrm{CaR}$

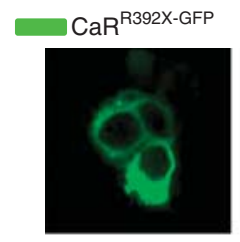

$\mathrm{CaR}^{\mathrm{R} 392 X-G F P}$

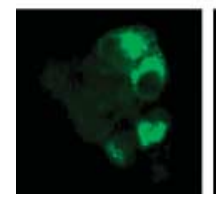

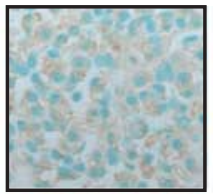

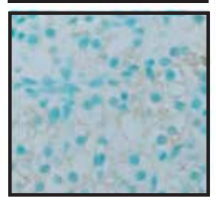

+ peptide ii) HEK-293

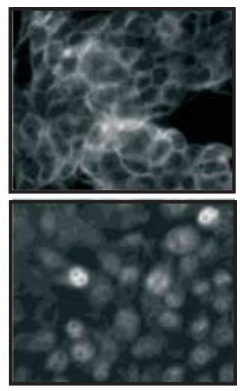

$1^{\circ} \mathrm{CaR}$
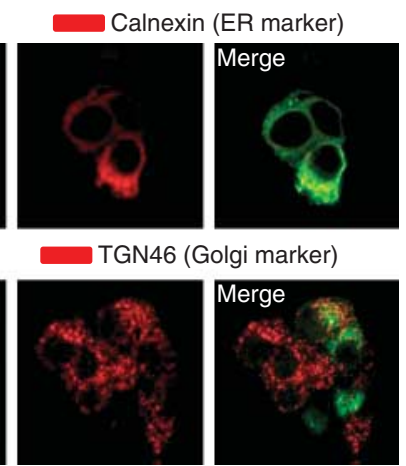

Figure 3 Wild-type (wt) CaR and $\mathrm{CaR}^{\mathrm{R} 392 \mathrm{X}}$ immunohistochemistry in human parathyroid gland and HEK-293 cells. (A) Parathyroid gland (PT) sections $(400 \times)$ (i) and HEK-293 cells transfected with either wt-CaR or $\mathrm{CaR}^{\mathrm{R} 392 \mathrm{x}}$; and (ii) probed with anti-CaR antibody in either the absence or the presence of immunising peptide (+ peptide). (B) Confocal microscopy analysis of CaRR392X immunolocalisation. HEK-293 cells transfected with CaR-R392X-GFP were stained with antibodies against calnexin and TGN46 to label the ER and Golgi respectively. The GFP signal (i.e. CaR-R392X) was found to overlap with ER.

CaR was detected in urine collected from the patient, despite the urinary proteins first being concentrated by centrifugation through filters with an appropriate pore size (Fig. 2D).

Immunohistochemistry of the patient's excised PT gland revealed very weak, intracellular CaR immunostaining compared with that observed in a gland from a patient with apparently normal CaR (Fig. 3Ai). Similarly, when wt $\mathrm{CaR}$ and $\mathrm{CaR}^{\mathrm{R} 392 \mathrm{X}}$ were expressed in HEK-293 cells, there was significant abundance of the wt receptor on or at the cell membrane, whereas the truncated mutant exhibited a diffuse, intracellular pattern (Fig. 3Aii). Cellular CaR localisation was further examined by immunofluorescence followed by confocal microscopy in which the cells were co-stained with markers for the endoplasmic reticulum (calnexin) and Golgi (TGN46). Here, CaR ${ }^{\text {R392X-GFP }}$ expression was also largely intracellular and located apparently within the endoplasmic reticulum, consistent with the expression of a non-functional receptor fragment (Fig. 3B).

Next, HEK-293 cells were transfected transiently with either wt-CaR or $\mathrm{CaR}^{\mathrm{R} 32 \mathrm{X}}$ to test whether the 

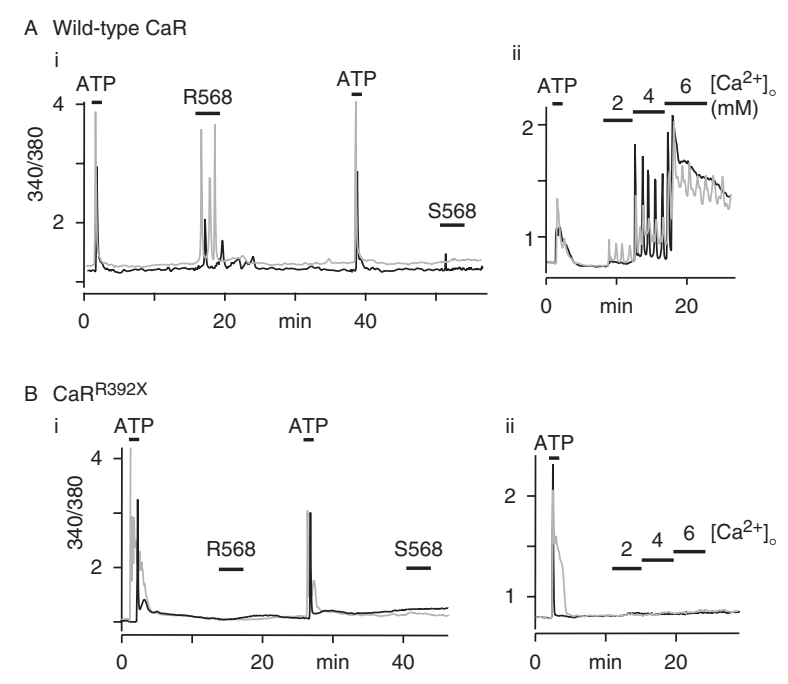

C

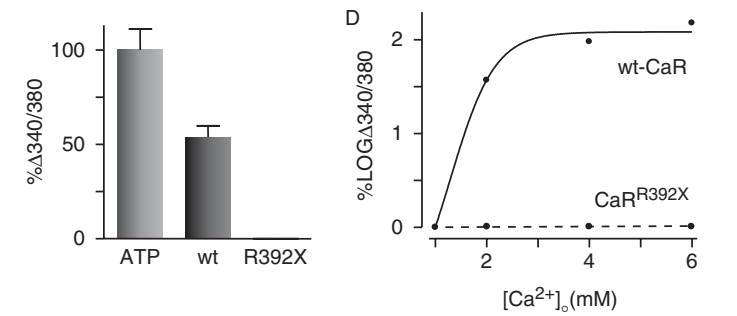

Figure 4 Functional analysis of intracellular calcium mobilisation by $\mathrm{CaR}^{\mathrm{R} 392 \mathrm{X}}$ in HEK-293 cells. (A and B) Fura2-loaded cells were exposed to either $5 \mu \mathrm{M}$ of the positive allosteric CaR modulator NPS-R568 (or its less active enantiomer NPS-S568); (i) or to increasing concentrations of $\mathrm{Ca}^{2+}$ o $(0.5-6 \mathrm{mM})$; (ii) with the resulting changes in $\mathrm{Ca}^{2+}{ }_{i}$ concentration measured by fluorescence microscopy. In each experiment, treatment with $100 \mu \mathrm{M}$ ATP was used as an internal control. Cells expressing wt-CaR exhibited $\mathrm{Ca}^{2+}{ }_{i}$ mobilisation in response to $\mathrm{CaR}$ stimulation $(\mathrm{A})$ whereas cells expressing $\mathrm{CaR}^{\mathrm{R} 392 \mathrm{X}}$ were unresponsive $(\mathrm{B})$. Each trace is representative of the $340 / 380 \mathrm{~nm}$ fluorescence ratios for three to four different experiments. (C) Bar graph showing the relative responses of wt-CaR and $\mathrm{CaR}^{\mathrm{R} 392 \mathrm{X}}$ to $5 \mu \mathrm{M}$ NPS-R568 exposure as a percentage of their maximal response to ATP pretreatment. (D) Concentration effect curve for $\mathrm{Ca}^{2+}{ }_{\circ}$ on wt-CaR and $\mathrm{CaR}^{\mathrm{R} 392 \mathrm{X}}$ where $\mathrm{CaR}$ response is expressed as \%LOG of the change in Fura ratio.

truncated receptor displays any functional activity. Cells transfected with wt receptor displayed classic CaR-like responses, namely concentration-dependent increases in $\mathrm{Ca}^{2+}{ }_{i}$ mobilisation in response to elevated $\mathrm{Ca}^{2+}{ }_{\mathrm{o}}$ concentration $(2-6 \mathrm{mM})$ and stereoselective responses (18) to the calcimimetic NPS-R568 (Fig. 4). In contrast, cells transfected with $\mathrm{CaR}^{\mathrm{R} 392 \mathrm{X}}$ exhibited no $\mathrm{Ca}^{2+}{ }_{\mathrm{i}}$ mobilisation in response to either $6 \mathrm{mM} \mathrm{Ca}^{2+}$ or $5 \mu \mathrm{M}$ NPS-R568. This lack of response was consistent for $100 \%$ of analysed cells (Fig. 4C). Taken together, these results confirm that $\mathrm{CaR}^{\mathrm{R} 392 \mathrm{X}}$ represents a completely non-functional receptor and that no read through of the stop codon occurs that might otherwise produce a full-length CaR.

\section{Discussion}

The proband expresses a novel CAR mutation in which the protein is truncated in the ECD and therefore cannot exist in the plasma membrane as a functional or even partially functional $\mathrm{CaR}$. The significance of this finding is that $\mathrm{CaR}^{\mathrm{R} 392 \mathrm{X}}$ represents a virtual human $C A R$ knockout. While $\mathrm{CaR}^{\mathrm{R} 392 \mathrm{X}}$ is not literally a human knockout having occurred naturally, we draw this metaphorical parallel because it is a GPCR fragment that lacks i) function, ii) a membrane anchorage and iii) exons 5-7. Indeed, the original Car knockout mouse lacked only exon 5 but still resulted in a NSHPT-like phenotype (19).

The $\mathrm{CaR}^{\mathrm{R} 392 \mathrm{X}}$ protein behaves as a disulphide-linked homodimer in HEK-293 cells, as would be expected given that it contains cysteine residues 129 and 131, which are believed to be responsible for such dimerisation (20). Further, this behaviour is consistent with that of the artificially truncated CaR ECD reported previously (21). Although we predicted that $\mathrm{CaR}^{\mathrm{R} 392 \mathrm{X}}$ should be detectable as a secreted fragment, we found no such CaR immunoreactivity in either conditioned media in vitro or in the patient's urine (even when concentrated) in vivo. This suggests either that the secreted fragment is quickly catabolised or that it fails to reach the membrane in the first place and undergoes intracellular degradation. This latter possibility is consistent with the intracellular localisation of the $\mathrm{CaR}^{\mathrm{R} 392 \mathrm{X}}$ immunoreactivity observed both in HEK-293 cells and, to a lesser extent, in the patient's own parathyroid cells. Specifically, the $\mathrm{CaR}^{\mathrm{R} 392 \mathrm{X}}$ fragment colocalised with the ER marker calnexin but not with the Golgi marker TGN46.

The absence of $\mathrm{CaR}^{\mathrm{R} 392 \mathrm{X}}$ from the plasma membrane most likely results from the lack of transmembrane regions necessary to anchor it there. However, as the $\mathrm{CaR}$ is expressed on the plasma membrane as a disulphide-linked homodimer $(16,20)$, then in theory, the $\mathrm{CaR}^{\mathrm{R} 392 \mathrm{X}}$ fragment might form a heterodimer in the heterozygous parents thus still impairing receptor function. In fact, there was little evidence of significantly dysfunctional calcium homeostasis in the parents, making it more likely that they express (mostly) wt CaR homodimers, although this was not tested further. Interestingly, however, six previously reported cases of FHH have been attributed to early truncations in the CaR ECD, namely $\mathrm{CaR}^{\mathrm{R} 25 \mathrm{X}}, \mathrm{CaR}^{\mathrm{K} 323 \mathrm{X}}$ (14), $\mathrm{CaR}^{\mathrm{W} 352 \mathrm{X}}, \mathrm{CaR}^{\mathrm{Y} 53 \mathrm{X}}(10), \mathrm{CaR}^{\mathrm{N583}}$ (12) and $\mathrm{CaR}^{\mathrm{S} 607 \mathrm{X}}$ (11). These cases suggest that such mutations can cause impaired calcium homeostasis in the heterozygote, although it is unclear whether this results from the formation of dysfunctional heterodimers or to a gene dosage effect resulting in reduced expression of wt CaR homodimers. The final prior report of NSHPT of direct relevance to the present case resulted from heterozygous expression in the same proband of two different early termination mutations, namely $\mathrm{CaR}^{\mathrm{G} 94 \mathrm{X}}$ and $\mathrm{CaR}^{\mathrm{R} 648 \mathrm{X}}(22)$. While $\mathrm{CaR}^{\mathrm{G} 94 \mathrm{X}}$ exhibited no 
membrane expression, as for $\mathrm{CaR}^{\mathrm{R} 392 \mathrm{X}}$ in the current study, $\mathrm{CaR}^{\mathrm{R} 648 \mathrm{X}}$ did achieve membrane localisation as it includes the first transmembrane span. Nevertheless, neither mutant CaR was functional resulting in NSHPT in which the child also exhibited impaired brain development at 4 months. In contrast, the proband in the current case, who had a parathyroidectomy in her second month, had a normal head CT scan at age 4 years and exhibits above average intelligence at age 11 years, adding weight to the idea that it may not be the total absence of functional CaR per se that causes the neurological impairment associated with some cases of NSHPT but prolonged hypercalcaemia $(22,23,24)$.

As only two parathyroid glands were located and excised during the parathyroidectomy, it is perhaps unsurprising that sufficient PTH secretion continued to maintain normocalcaemia. As no additional glands were located by subsequent sestamibi scan, it is likely that the residual PTH secretion might derive from multiple small parathyroid clusters reported to sometimes develop in addition to the main parathyroid glands (25). Interestingly, however, there was no recurrence of the pathological rise in PTH secretion despite the apparent absence of CaR-mediated feedback. Finally, at peripubescence, the proband's residual PTH secretion appeared unable to meet the additional calcium demand and remained inappropriately normal despite hypocalcaemia. For post-parathyroidectomy NSHPT patients, it is worth noting that the lack of renal CaR activity may actually help with calcium preservation. That is, CaR expressed on the basolateral surface of cortical thick ascending limb tubule normally limits divalent cation reabsorption by attenuating the lumen-positive potential difference across the epithelium. Indeed, the proband's urinary $\mathrm{Ca}$ :Cr ratios were low ( 0.16 at age 7 years and 0.22 at age 8 years) as expected for loss-of-function CaR mutation.

In conclusion, with so many potential effects for CaR hypothesised both within and without the calcium homeostatic system $(26,27)$, long-term follow-up of this patient (and the other related instances of early termination in the CaR ECD) could provide a unique insight into the extra-calciotropic consequences of a 'CAR-null' condition in humans.

\section{Supplementary data}

This is linked to the online version of the paper at http://dx.doi.org/ 10.1530/EJE-13-0094.

\section{Declaration of interest}

The authors declare that there is no conflict of interest that could be perceived as prejudicing the impartiality of the research reported.

\section{Funding}

The in vitro work was funded in part by grants from Kidney Research UK (TF6/2002 and IN4/2008).

\section{Acknowledgements}

The authors would like to thank Prof. Raj Thakker and Dr Treena Cranston (University of Oxford) for their assistance with the gene sequencing, Dr David Maldonado-Pérez (University of Edinburgh) for making the $\mathrm{CaR}^{\mathrm{R} 392 \mathrm{X}}$-GFP construct, Ms Kathryn Bailey (University of Manchester) for her technical assistance and Prof. Arthur Conigrave for helpful discussions (University of Sydney).

\section{References}

1 Hendy GN, Guarnieri V \& Canaff L. Calcium-sensing receptor and associated diseases. Progress in Molecular Biology and Translational Science $2009 \mathbf{8 9}$ 31-95. (doi:10.1016/S1877-1173(09) 89003-0)

2 Thakker RV. Diseases associated with the extracellular calciumsensing receptor. Cell Calcium 200435 275-282. (doi:10.1016/ j.ceca.2003.10.010)

3 Ward BK, Magno AL, Walsh JP \& Ratajczak T. The role of the calcium-sensing receptor in human disease. Clinical Biochemistry 201245 943-953. (doi:10.1016/j.clinbiochem.2012.03.034)

4 Tõke J, Czirják G, Patócs A, Enyedi B, Gergics P, Csákváry V, Enyedi P \& Tóth M. Neonatal severe hyperparathyroidism associated with a novel de novo heterozygous $\mathrm{R} 551 \mathrm{~K}$ inactivating mutation and a heterozygous A986S polymorphism of the calcium-sensing receptor gene. Clinical Endocrinology 200767 385-392. (doi:10.1111/j.1365-2265.2007.02896.x)

5 Hannan FM, Nesbit MA, Zhang C, Cranston T, Curley AJ, Harding B, Fratter C, Rust N, Christie PT, Turner JJ et al. Identification of 70 calcium-sensing receptor mutations in hyper- and hypo-calcaemic patients: evidence for clustering of extracellular domain mutations at calcium-binding sites. Human Molecular Genetics 201221 2768-2778. (doi:10.1093/hmg/ dds105)

6 Chang W, Tu C, Chen TH, Bikle D \& Shoback D. The extracellular calcium-sensing receptor (CaSR) is a critical modulator of skeletal development. Science Signaling 20081 ra1. (doi:10.1126/ scisignal.1159945)

7 Toka HR, Al-Romaih K, Koshy JM, DiBartolo S III, Kos CH, Quinn SJ, Curhan GC, Mount DB, Brown EM \& Pollak MR. Deficiency of the calcium-sensing receptor in the kidney causes parathyroid hormone-independent hypocalciuria. Journal of the American Society of Nephrology 201223 1879-1890. (doi:10.1681/ASN. 2012030323)

8 Al-Khalaf FA, Ismail A, Soliman AT, Cole DE \& Ben-Omran T. Neonatal severe hyperparathyroidism: further clinical and molecular delineation. European Journal of Pediatrics 2011170 625-631. (doi:10.1007/s00431-010-1335-z)

9 Kobayashi M, Tanaka H, Tsuzuki K, Tsuyuki M, Igaki H, Ichinose Y, Aya K, Nishioka N \& Seino Y. Two novel missense mutations in calcium-sensing receptor gene associated with neonatal severe hyperparathyroidism. Journal of Clinical Endocrinology and Metabolism 199782 2716-2719. (doi:10.1210/ jc.82.8.2716)

10 Nissen PH, Christensen SE, Heickendorff L, Brixen K \& Mosekilde L. Molecular genetic analysis of the calcium sensing receptor gene in patients clinically suspected to have familial hypocalciuric hypercalcemia: phenotypic variation and mutation spectrum in a Danish population. Journal of Clinical Endocrinology and Metabolism 200792 4373-4379. (doi:10.1210/jc.2007-0322)

11 Pearce SH, Trump D, Wooding C, Besser GM, Chew SL, Grant DB, Heath DA, Hughes IA, Paterson CR, Whyte MP et al. Calciumsensing receptor mutations in familial benign hypercalcemia and neonatal hyperparathyroidism. Journal of Clinical Investigation 199596 2683-2692. (doi:10.1172/JCI118335)

12 Pidasheva S, Grant M, Canaff L, Ercan O, Kumar U \& Hendy GN. Calcium-sensing receptor dimerizes in the endoplasmic 
reticulum: biochemical and biophysical characterization of CASR mutants retained intracellularly. Human Molecular Genetics 2006 15 2200-2209. (doi:10.1093/hmg/ddl145)

13 Waller S, Kurzawinski T, Spitz L, Thakker R, Cranston T, Pearce S, Cheetham T \& van't Hoff WG. Neonatal severe hyperparathyroidism: genotype/phenotype correlation and the use of pamidronate as rescue therapy. European Journal of Pediatrics 2004 163 589-594. (doi:10.1007/s00431-004-1491-0)

14 Ward BK, Magno AL, Blitvich BJ, Rea AJ, Stuckey BG, Walsh JP \& Ratajczak T. Novel mutations in the calcium-sensing receptor gene associated with biochemical and functional differences in familial hypocalciuric hypercalcaemia. Clinical Endocrinology $2006 \mathbf{6 4}$ 580-587. (doi:10.1111/j.1365-2265.2006.02512.x)

15 Garrett JE, Capuano IV, Hammerland LG, Hung BCP, Brown EM, Hebert SC, Nemeth EF \& Fuller F. Molecular cloning and functional expression of human parathyroid calcium receptor cDNAs. Journal of Biological Chemistry $1995 \mathbf{2 7 0} 12919-12925$. (doi:10.1074/jbc.270.21.12919)

16 Ward DT, Brown EM \& Harris HW. Disulfide bonds in the extracellular calcium-polyvalent cation-sensing receptor correlate with dimer formation and its response to divalent cations in vitro. Journal of Biological Chemistry 1998273 14476-14483. (doi:10.1074/jbc.273.23.14476)

17 Ward DT, McLarnon SJ \& Riccardi D. Aminoglycosides increase intracellular calcium levels and ERK activity in proximal tubular OK cells expressing the extracellular calcium-sensing receptor Journal of the American Society of Nephrology 200213 1481-1489. (doi:10.1097/01.ASN.0000015623.73739.B8)

18 Nemeth EF, Steffey ME, Hammerland LG, Hung BC, Van Wagenen BC, DelMar EG \& Balandrin MF. Calcimimetics with potent and selective activity on the parathyroid calcium receptor. PNAS 199895 4040-4045. (doi:10.1073/pnas.95.7.4040)

19 Ho C, Conner DA, Pollak MR, Ladd DJ, Kifor O, Warren HB, Brown EM, Seidman JG \& Seidman CE. A mouse model of human familial hypocalciuric hypercalcemia and neonatal severe hyperparathyroidism. Nature Genetics 199511 389-3894. (doi:10.1038/ng1295-389)

20 Bai M. Structure-function relationship of the extracellular calciumsensing receptor. Cell Calcium 200435 197-207. (doi:10.1016/ j.ceca.2003.10.018)
21 Goldsmith PK, Fan GF, Ray K, Shiloach J, McPhie P, Rogers KV \& Spiegel AM. Expression, purification, and biochemical characterization of the amino-terminal extracellular domain of the human calcium receptor. Journal of Biological Chemistry 1999274 11303-11309. (doi:10.1074/jbc.274.16.11303)

22 Ward BK, Magno AL, Davis EA, Hanyaloglu AC, Stuckey BG, Burrows M, Eidne KA, Charles AK \& Ratajczak T. Functional deletion of the calcium-sensing receptor in a case of neonatal severe hyperparathyroidism. Journal of Clinical Endocrinology and Metabolism 200489 3721-3730. (doi:10.1210/jc.2003031653)

23 Cole De, Forsythe CR, Dooley JM, Grantmyre EB \& Salisbury SR. Primary neonatal hyperparathyroidism: a devastating neurodevelopmental disorder if left untreated. Journal of Craniofacial Genetics and Developmental Biology 199010 205-214.

24 Chikatsu N, Fukumoto S, Suzawa M, Tanaka Y, Takeuchi Y, Takeda S, Tamura Y, Matsumoto T \& Fujita T. An adult patient with severe hypercalcaemia and hypocalciuria due to a novel homozygous inactivating mutation of calcium-sensing receptor. Clinical Endocrinology $1999 \mathbf{5 0}$ 537-543. (doi:10.1046/ j.1365-2265.1999.00729.x)

25 Liu Z, Farley A, Chen L, Kirby BJ, Kovacs CS, Blackburn CC \& Manley NR. Thymus-associated parathyroid hormone has two cellular origins with distinct endocrine and immunological functions. PLoS Genetics 20106 e1001251. (doi:10.1371/ journal.pgen.1001251)

26 Riccardi D \& Kemp PJ. The calcium-sensing receptor beyond extracellular calcium homeostasis: conception, development, adult physiology, and disease. Annual Review of Physiology 2012 74 271-297. (doi:10.1146/annurev-physiol-020911-153318)

27 Bandyopadhyay S, Tfelt-Hansen J \& Chattopadhyay N. Diverse roles of extracellular calcium-sensing receptor in the central nervous system. Journal of Neuroscience Research 201088 20732082. (doi:10.1002/jnr.22391)

Received 30 January 2013

Revised version received 10 April 2013

Accepted 23 April 2013 